\title{
Implementasi Media Pembelajaran Domino Braille Dalam Meningkatkan Kemampuan Berhitung Siswa Tunanetra
}

\author{
Lediana Rosa Rosmino', ST Asdianti², Resky Rahmayanti ${ }^{3}$, Fitriani $^{4}$ \\ 1,2,3,4 Pendidikan Guru Sekolah Dasar, Fakultas Keguruan dan Ilmu Pendidikan \\ Universitas Muhammadiyah Makassar, Indonesia \\ Email: ledianarosa110@gmail.com
}

\begin{abstract}
ABSTRAK
Penelitian ini merupakan Penelitian Tindakan Kelas yang meliputi tahapan-tahapan pelaksanaan: perencanaan, pelaksanaan, observasi dan refleksi. Dengan tujuan untuk mengetahui meningkatnya motivasi belajar siswa tunanetra Sekolah Dasar SLB Negeri 1 Makassar dengan menerapkan media pembelajaran domino braille. Teknik analisis data dalam penelitian ini adalah analisis secara kualitatif dan analisis secara kuantitatif dengan data yang diperoleh dari pelaksanaan observasi selama penelitian. Ketuntasan belajar siswa tunanetra di sekolah termasuk dalam kategori belum tuntas. Pada siklus II ketuntasan belajar siswa meningkat sehingga termasuk dalam kategori tuntas. Ini menandakan bahwa ketuntasan belajar siswa tunanetra pada siklus II mengalami peningkatan dan mencapai ketuntasan. Namun hasil yang dharapkan pada siklus II belum sesuai target maka dilakukan refleksi untuk perbaikan pada siklus III. Ketuntasan belajar siswa tunanetra di sekolah pada siklus III sehingga diperoleh data termasuk dalam kategori tuntas. Berdasarkan hasil penelitian dan pembahasan dapat disimpulkan bahwa dengan menerapkan media pembelajaran domino karakter dapat meningkatkan motivasi belajar siswa dalam pembelajaran berhitung siswa tunanetra sekolah dasar SLB Negeri 1 Makassar selama proses pembelajaran.
\end{abstract}

Kata Kunci: Berhitung; Domino Braille; Tunanetra

\begin{abstract}
This research is a classroom action research) which includes the stages of implementation: planning, implementation, observation and reflection. With the aim of knowing the increase in learning motivation of blind students at SLB Negeri 1 Makassar Elementary Schoolbyapplying domino braille learning media. The data analysis technique in this study is qualitative analysis and quantitative analysis with data obtained from the implementation of observationsduring the study. Complete learning of blind students in schools is included in the unfinished category. In the second cycle, student learning completeness increased so that it was included in the complete category. This indicates that the learning completeness of blind students in cycle II hasincreased and achieved completeness. However, the expected results in the second cycle havenotmet the target, so a reflection is carried outfor improvements in the third cycle. Complete learning of autistic students in school in cycle III so that the data obtained are included in the complete category. Based on the results of the research and discussion, it can be concluded that by applying the domino character learning media, it can increase students' motivation in learning arithmetic for blind students at SLB Negeri 1 Makassar elementary school during the learning process.
\end{abstract}

Keywords: Counting; Domino Braille; Blind

(C) 2021 Lediana Rosa Rosmino, ST Asdianti, Resky Rahmayanti, Fitriani Under th license CC BY-SA 4.0

Pedagogika.fip@ung.ac.idＰ-ISSN: 2086-4469Ｅ-ISSN: 2716-0580 
PEDAGOGIKA

Volume 12 (Nomor 2) 2021

Hal. 176-183

\section{PENDAHULUAN}

Anak berkebutuhan khusus atau disabilitas sering disebut sebagai orang cacat yang dianggap sebagai warga masyarakat yang tidak mampu menjalankan tugas dan tanggungjawab sehingga hak-haknya pun diabaikan. Banyaknya jumlah penyandang disabilitas, tidak menjadi perbedaan perlakuan dan pemenuhan hak antara orang yang normal dengan penyandang disabilitas. Anak berkebutuhan khusus memiliki cara belajarnya sendiri seperti menggunakan peralatan yang memudahkan mereka dalam memperoleh ilmu. Sebagai seorang pendidik maupun orangtua menyediakan alat yang dapat mendukung motoriknya. Salah satunya anak tunanetra yang menggunakan fungsi indranya seperti peraba dan pendengaran. Walau memiliki keterbatasan dalam indra penglihatan namun aktivitas belajar siswa tunanetra cukup unik. Saat di sekolah tunanetra dapat membaca dan menulis mereka membaca memakai buku berhuruf braille dan menggunakan kertas braille untuk menulis (Rahmalia, 2019).

Dalam proses belajar mengajar dua unsur yang amat penting adalah metode mengajar dan media pembelajaran, saat ini banyak guru yang terpaku dalam satu model pembelajaran yang digunakan dalam proses belajar mengajar secara terus menerus. Hal ini dapat mengakibatkan pencapaian tujuan pembelajaran tidak optimal, dari seluruh mata pelajaran yang ada mata pelajaran yang sering dianggap sulit oleh peserta didik adalah matematika. Hal ini disebabkan karena matematika merupakan mata pelajaran yang memerlukan ketelitian dan pemikiran yang tinggi. Selain itu penalaran dan logika yang kuat diperlukan dalam belajar matematika, pada peserta didik belajar melalui benda atau objek konkret (Nurfiriyanti, 2016).

Media dalam pembelajaran matematika diperlukan untuk mempermudah namun, kebanyakan guru hanya menjelaskan dan mempraktekkan cara melakukan penjumlahan, pengurangan, penjumlahan, dan pembagian. Disini guru hanya menerangkan dan memberikan tugas yang telah ditulis guru dikertas dengan menggunkan tulisan braille, jadi anak hanya mencari hasil dari penjumlahan, pengurangan, perkalian dan pembagian yang diberikan oleh guru. Adapun media dan metode yang diberikan guru dalam pembelajaran matematika yang kurang bervariasi contohnya pada saat guru memberikan materi guru hanya memakai metode ceramah sehingga siswa merasa jenuh saat pembelajaran berlangsung (Rindiani, 2019). Permasalahan dalam pembelajaran matematika operasi hitung kelas V yaitu keterbatasan dalam media pembelajaran yang digunakan sehingga memungkinkan siswa merasa jenuh dan bosa dalam menangkap materi yang dijelaskan oleh guru (Karnadi, 2018).

Para penderita tunanetra huruf braille seolah menjadi kebutuhan khusus dalam proses pembelajaran. Oleh sebab itu anak tunanetra membutuhkan strategi pembelajaran dalam pendidikan sehingga memberikan dampak yang baik bagi perkembangannya. Salah satu cara yang digunakan adalah dengan menggunakan 
media pembelajaran seperti permainan kartu yang dimana permainan ini juga memperkenalkan anak tentang angka itu sendiri. Selain menggunakan buku juga menyediakan sebuah media agar anak tidak merasa cepat bosan disamping itu dapat melatih motorik anak. Media Pembelajaran yang diterapkan pada anakanak tunanetra di beberapa Sekolah Luar Biasa (SLB) meliputi: alat bantu menulis huruf braille, alat bantu membaca huruf braille, alat bantu berhitung, serta alat bantu yang bersifat audio. Khusus Alat bantu membaca huruf braille adalah alat bantu pembelajaran untuk mengenal huruf (Kurniawan, 2015).

Dalam penelitian Dennis Meilky La'lang (2016) dengan judul Pemanfaatan Bola Sebagai Alat Perga Untuk Membantu Siswa Sekolah Luar Biasa Tunanetra (SLB A) Memahami Konsep Perkalian. Di dalam penelitian ini bertujuan untuk mengetahui hasil belajar siswa yang dicapai siswa kelas II SLB A Yaketunis Yogyakarta dalam pembelajaran matematika dengan menggunakan bola sebagai alat peraga

\section{METODE PENELITIAN}

Jenis penelitian yang digunakan yaitu penelitian kualitatif. Penelitian kualitatif merupakan suatu penelitian yang digunakan untuk meneliti pada objek yang alamiah dimana peneliti adalah sebagai instrumen kunci, teknik pengumpulan data dilakukan secara gabungan, analisis data bersifat induktif, dan hasil penelitian kualitatif lebih menekankan makna daripada generalisasi. Penelitian ini dilaksanakan di sekolah SLB pembina Tk. Provinsi pada materi perkalian dan mengetahui pengaruh penggunaan bola sebagai alat peraga dalam pembelajaran matematika terhadap pemahaman siswa SLB A pada materi perkalian. Peneleitian yang kami lakukan ini berbeda dengan penelitian yang kami lakukan yaitu dimana disini difokuskan pada anak tunanetra dalam melakukan pembelajaran operasi hitung. Penelitian ini mengarah pada pengimplementasian media pembelajaran. Hasil penelitian diharapkan dapat menjadi bahan referensi untuk pengembangan pendidikan dan mengatasi rendahnya kemampuan operasi hitung serta meningkatkan minat belajar khususnya penderita tunanetra serta menjadi bahan masukan untuk guru atau tenaga pengajar. Penelitian ini diharapkan dapat membantu tenaga pengajar atau pendidik dalam mengatasi anak tunanetra dalam belajar berhitung serta hasil penelitian ini dapat menambah wawasan dan referensi tentang medi pembelajaran domino braille dalam berhitung.

Sulawesi Selatan. Kegiatan penelitian ini dilaksanakan dalam jangka waktu tiga bulan, yaitu bulan juni-agustus 2021 .

Sugiyono (2014) menyatakan bahwa 'Instrumen penelitian adalah suatu alat pengumpulan data yang digunakan untuk mengukur fenomena alam maupun sosial yang diamati”. Dengan demikian, penggunaan instrument penelitian yaitu untuk mencari informasi yang lengkap mengenai suatu masalah, fenomena alam maupun sosial. 
Instrumen penelitian yang digunakan dalam penelitian ini berupa pedoman wawancara, pedoman observasi, tes, angket respon, catatan lapangan, dokumentasi dan perekam suara.

Teknik pengumpulan data yang digunakan yaitu ada tiga sebagai berikut:

\section{Tes}

Tes merupakan cara untuk mengetahui tingkat pemahaman peserta didik terhadap materi operasi hitung yang telah diajarkan. Tes dilakukan setelah peserta didik melakukan proses belajar mengajar menggunakan domino braille.

\section{Observasi/Pengamatan}

Observasi merupakan cara untuk menganalisa dan melakukan pencatatan dari suatu tindakan dengan atau aktivitas dalam rposes pembelajaran secara langsung dengan teliti, cermat dan hati-hati terhadap fenomena yang ada.

3. Angket Respon

Angket diberikan pada siswa untuk mengetahui respon siswa terhadap penerapan permainan domino karakter. Angket diberikan setelah melakukan pembelajaran.

\section{Catatan Lapangan}

Catatan lapangan merupakan catatan penulis tentang apa yang didengar, dilihat, dialami dan dipikirkan dalam rangka pengumpulan data dan refleski terhadap data dalam penelitian kualitatif.

\section{Dokumentasi}

Dokumentasi merupakan metode untuk memperoleh atau mengetahui sesuatu dengan buku-buku, arsip yang berhubungan dengan yang diteliti. Dokumentasi digunakan untuk memperoleh data sekolah dan identitas siswa antara lain; nama siswa dan nomor induk sswa dengan melihatd okumen yang ada di sekolah serta foto rekaman proses tindakan penelitian.

Teknik analisis data yang digunakan dalam penelitian ini meliputi teknik metode gabungan (Mixed Methods Research) yaitu: 1) Analisis data kualitatif yang terdiri dari wawancara, observasi dan dokumentasi; 2) Analisis data kuantitatif digunakan untuk mendeskripsikam tentang efektivitas dari pembelajaran yang meliputi hasil belajar siswa tunanetra. Hasil belajar siswa tunanetra ditentukan dari hasil penilaian kemampuan menyelesaikan soal dengan baik berdasarkan rubrik penilaian yang disusun. Sedangkan peningkatan pembelajaran ditentukan berdasarkan pencapaian pada aspek-aspek hasil tes belajar siswa. Dalam penelitian ini analisis dilakukan dalam tiga tahap yang meliputi; 1) Reduksi data; 2) Penyajian data; 3) Penarikan kesimpulan.

\section{Analisis Data Hasil Observasi}

Analisis data observasi diperoleh dari pengamatan melalui pemberian skor sesuai dengan pedoman penskoran pada kisi-kisi lembar observasi yang telah dibuat. Menghitung skor total yang telah diperoleh setelah pelaksanaan pembelajaran. Skor total yang telah diperoleh dihitung persentase dengan menggunakan rumus presentase sebagai berikut.

$$
\mathrm{P}=\frac{F}{N} \times 100 \%
$$


Keterangan:

$\mathrm{P} \quad$ : Persentase
F : Jumlah skor yang diperoleh

$\mathrm{N}$ : Jumlah skor maksimal

Tabel 1 Klasifikasi Persentase Hasil Observasi Guru Dan Siswa

\begin{tabular}{ccc}
\hline Skor & Persentase & Kriteria \\
\hline $10-13$ & $0 \%-25 \%$ & Sangat Kurang \\
$14-17$ & $26 \%-45 \%$ & Kurang \\
$18-21$ & $46 \%-69 \%$ & Cukup \\
$22-25$ & $70 \%-85 \%$ & Baik \\
$26-36$ & $86 \%-100 \%$ & Sangat Baik \\
\hline
\end{tabular}

2. Hasil Analisis Tes

Untuk memperoleh persentase hasil analisis tes dalam kegiatan pembelajaran maka digunakan rumus juga rumus presentase.
Hasil analisis dari persentase tersebut dapat dibuat kesimpulan tentang respon siswa menggunakan skala Likert dengan kriteria sebagai berikut

Tabel 2 Klasifikasi Persentase Nilai Hasil Belajar Siswa

\begin{tabular}{ccc}
\hline Skor & Persentase & Kriteria \\
\hline $0-37$ & $0 \%-25 \%$ & Sangat Kurang \\
$37-56$ & $26 \%-45 \%$ & Kurang \\
$55-65$ & $46 \%-69 \%$ & Cukup \\
$66-75$ & $70 \%-85 \%$ & Baik \\
$76-100$ & $86 \%-100 \%$ & Sangat Baik \\
\hline
\end{tabular}

\section{HASIL DAN PEMBAHASAN}

Hasil dari penelitian ini adalah menjelaskan terkait analisis media pembelajaran domino braille.

\section{Hasil Penelitian}

\section{a. Deskripsi Nilai Hasil} Belajar Sis wa

Data kemampuan berhitung diperoleh melalui tes yang dilakukan sebelum treatment. Tes yang diberikan berjumlah 20 soal. 5 soal penjumlahan, 5 soal pengurangan, 5 soal perkalian dan 5 soal pembagian. Berikut data hasil kemampuan berhitung sebelum dilakukan perlakuan. 
Tabel 3 Data Hasil Belajar Siswa dan Observasi Aktivitas Siswa

\begin{tabular}{|c|c|c|c|c|c|c|c|}
\hline \multirow{3}{*}{ No } & \multirow{3}{*}{ Keterangan } & \multicolumn{6}{|c|}{ Nilai Test } \\
\hline & & \multicolumn{2}{|c|}{ Siklus I } & \multicolumn{2}{|c|}{ Siklus II } & \multicolumn{2}{|c|}{ Siklus III } \\
\hline & & Pretest & Postest & Pretest & Postest & Pretest & Postest \\
\hline 1. & Rata-rata & 62,5 & 77,5 & 70 & 87,5 & 75 & 90 \\
\hline 2. & $\begin{array}{l}\text { Skor } \\
\text { tertinggi }\end{array}$ & 65 & 80 & 90 & 85 & 90 & 90 \\
\hline 3. & $\begin{array}{c}\text { Skor } \\
\text { terendah }\end{array}$ & 60 & 75 & 70 & 70 & 80 & 70 \\
\hline
\end{tabular}

b. Deskripsi Hasil Observasi Aktivitas Siswa

Berdasarkan hasil skor pada lembar obsrvasi aktivitas siswa dapat kita lihat pada tabel berikut.

Tabel 4 Hasil Observasi Hasil Aktivitas Siswa

\begin{tabular}{lccccc}
\hline No & $\begin{array}{c}\text { Komponen } \\
\text { Analisis }\end{array}$ & I & Siklus & Peningkatan \\
& Pertemuan I & $41,97 \%$ & $50,61 \%$ & $55,55 \%$ & $49 \%$ \\
\hline 1 & Pertemuan II & $42 \%$ & $53,08 \%$ & $65,42 \%$ & $53 \%$ \\
3 & Pertemuan III & $66,66 \%$ & $70,36 \%$ & $74,06 \%$ & $70 \%$ \\
\hline
\end{tabular}

c. Deskripsi Observasi Hasil Aktivitas Guru

Berdasarkan hasil skor pada lembar obsevasi aktivitas guru yang terlihat pada tabel berikut.

Tabel 5 Hasil Observasi Hasil Aktivitas Guru

\begin{tabular}{lccccc}
\hline No & $\begin{array}{c}\text { Komponen } \\
\text { Analisis }\end{array}$ & I & Siklus & III & Peningkatan \\
& Pertemuan I & $20 \%$ & $20 \%$ & $20 \%$ & $20 \%$ \\
2 & Pertemuan II & $26 \%$ & $26 \%$ & $27 \%$ & $26 \%$ \\
3 & Pertemuan III & $31 \%$ & $33 \%$ & $35 \%$ & $33 \%$ \\
\hline
\end{tabular}

\section{Pembahasan}

Berdasarkan hasil analisis terlihat bahwa pada dasarnya pelaksanaan pembelajaran dengan menggunakan penerapan domino braille mampu memberikan perubahan kepada siswa tunanetra. Bisa kita lihat sebelum dan setelah dilakukannya perlakuan. Terlihat bahwa siswa tunanetra sedikit lebih termotivasi untuk mengikuti pelajaran karena pembelajaran yang diberikan tergolong baru menurut pandangan mereka, meski siswa tunanetra kurang fokus dan kurang memperhatikan peneliti.Meski tunanetra meras canggung dan kurang memperlihatkan adaptasinya terhadap peneliti. Sehingga seolah-olah siklus I ini masih orientasinya siswa mengenali model yang diterapkan,, sedangkan 
guru dapat mengenali karakter individu.

Setelah diadakan refleksi pada siklus I, maka dilakukan perbaikan kegiatan yang dianggap perlu demi meningkatkan hasil belajar siswa tuanetra pada siklus II dan III, dapat dilihat bahwa motivasi belajar siswa tunanetra mengalami peningkatan. Ketercapaian harapan tersebut dapat meningkat karena model pembelajarannya berupa media permainan domino braille. Disamping terjadinya peningkatan sikap interaksi, sosial, motorik dan perilaku. Perubahan tersebut merupakan data kualitatif yang diperoleh dari lembar observasi pada setiap pertemuan. Selama pelaksanaan tindakan dari siklus I, siklus II dan siklus III dapat dilihat bahwa persentase hasil belajar, aktivitas siswa dan aktivitas pendampingan

\section{SIMPULAN}

Berdasaarkan hasil penelitian dan pembahasan dapat disimpulkan bahwa dengan penerapan media pembelajaran domino braille dapat meningkatkan motivasi belajar siswa dalam pembelajaran berhitung yang ditandai dengan meningkatnya hasil belajar siswa tunanetra sekolah dasar SLB Negeri 1 Makassar selama proses pembelajaran berjalan. Dari belajar, peneliti dapat mengambil kesimpulan dari hasil pengamatan bahwa terjadi peningkatan secara signifikan. Dari ketiga siklus tersebut merupakan data kuantitatif yang diperoleh selama tindakan. Perubahan-perubahan yang dimaksud adalah:

1) Persentase aktivitas siswa di sekolah pada siklus I diperoleh sebesar $49 \%$, siklus II $53 \%$ dan siklus III $70 \%$.

2) Persentase aktivitas pendampingan guru pada siklus I diperoleh sebesar 20\%, siklus II $26 \%$ dan siklus III $33 \%$.

3) Persentase hasil belajar siswa di sekolah pada siklus I sebesar pretest $62,5 \%$ dan postest 77,5, siklus II pretest $70 \%$ dan postest $87,5 \%$, siklus III pretest $75 \%$ dan postest $90 \%$. data yang diperoleh, perbandingan antara pendampingan belajar yang dilakukan oleh guru di sekolah terhadap siswa tunanetra memiliki perbedaan, hal itu dapat dilihat pada hasil analisis siklus III bahwa persentase hasil belajar siswa. Pendampingan guru dan orangtua diperlukan diakibatka pembelajaran jarak jauh.

\section{REFERENSI}

Karnadi. 2018. Pengembangan Media Monopoli Braille pada
Pelajaran Matematika dalam Materi Operasi Hitung Campur 
bagi Peserta Didik Tunanetra Kelas V SDLB Negeri Lamongan. Skripsi. Universitas Negeri Malang.

Kurniawan, I. 2015. Implementasi Pendidikan Bagi Siswa Tunanetra Di Sekolah Dasar Inklusi. Jurnal Pendidikan Islam. 4: 1051-1052.

La'lang, D. M. 2016. Pemanfaatan Bola Sebagai Alat Peraga Untuk Membantu Siswa Sekolah Luar Biasa Tunanetra (SLB A) Memahami konsep perkalian. Skripsi. Universitas Sanata Dharma.

Nurfitriyanti, M., dkk. 2016. Penggunaan Alat Peraga Kartu Domino Terhadap Hasil Belajar Matematika. Jurnal Kebijakan dan Manajemen Publik. 1 (2): 249.

Rahmalia, I. 2019. Yuk, Kita Intip Cara Belajar Siswa Tunanetra. https://bobo.grid.id/amp/08164 5990/yuk-kita-intip-cara-

belajar-siswatunanetra?page=all. Di akses tanggal 30 Juni2020 pada pukul (15.17).

Rindiani dan Irdamurni. 2019. Media Blokjes untuk Meningkatkan Kemampuan Operasi Hitung Anak Tunanetra. Jurnal Penelitian Pendidikan Kebutuhan Khusus. 7(1) : 149.

Sugiyono. 2014. Metode Penelitian Kuantitatif, Kualitatif, dan $R \& D$. Cetakan 20. Alfabeta. Bandung. 